\title{
Ground-penetrating radar profiling on embanked floodplains
}

\author{
M.A.J. Bakker ${ }^{\star}$, D. Maljers \& H.J.T. Weerts \\ TN0 Built Environment and Geosciences - Netherlands Geological Survey, Princetonlaan 6, 3508 TA Utrecht, the Netherlands. \\ * Corresponding author. Email: marcel.bakker@tno.nl
}

Manuscript received: May 2006; accepted: April 2007

\begin{abstract}
Management of the Dutch embanked floodplains is of crucial interest in the light of a likely increase of extreme floods. One of the issues is a gradual decrease of floodwater accommodation space as a result of overbank deposition of mud and sand during floods. To address this issue, sediment deposits of an undisturbed embanked floodplain near Winssen along the river Waal were studied using ground-penetrating radar (GPR). A number of radar facies units were recognized. Boreholes were used to relate radar facies units to sedimentary facies and to determine radar velocity. The GPR groundwave is affected by differences in moisture and texture of the top layer and probably interferes with the first subsurface reflector. The architectural elements recognized in the GPR transects confirm earlier reported insights on human-influenced river behaviour. This is testified in the development of sand bars during flood regimes that are probably more widespread than previously established.
\end{abstract}

Keywords: floodplain, overbank sediments, GPR (ground-penetrating radar), radar facies

\section{Introduction}

The extreme floods of 1993/94 and 1995 have demonstrated that river management is of crucial interest for the Dutch population, of which most live below flood stage level. Middelkoop (1997) has shown how embanked floodplains along the major rivers in the central Netherlands have experienced gradual decrease in accommodation space due to frequent deposition of mud drapes and sand during floods. Middelkoops results were based on the examination of historical maps and geochemical characterization of heavy metals in overbank deposits. In the light of a likely increase in extreme floods in the near future, river management is increasingly dependent on accurate assessment of recent sedimentation rates in the embanked floodplains and the resultant decrease of accommodation space. Assessment of sedimentation rates in embanked floodplains is also of interest for sand and clay exploitation in these areas.

In order to develop new research techniques for measuring sedimentation rates on embanked floodplains, an example near Winssen, along the river Waal, was studied. This site was selected because it is (largely) undisturbed and has the availability of historical age control.

Following Middelkoops' findings, sedimentation on floodplains is now studied using a combination of geophysical profiling, coring, geochemical analysis and OSL dating. This multidisciplinary approach allows a more comprehensive description and interpretation of overbank sedimentation. The purpose of this paper is to discuss the results of the geophysical profiling.

\section{Geological and historical setting of the Rhine-Meuse floodplain near Winssen}

The embanked floodplain of Winssen is situated along the river Waal, the major branch of the Rhine (Fig. 1). Between 1050 and $1350 \mathrm{AD}$ the Waal was embanked by man (Pons, 1957) and the original floodplains (Fig. 1) were isolated from the active river. Between the time of the embankment and about $1600 \mathrm{AD}$, the confined river channel eroded parts of the pre-embankment deposits within the channel between the embankments (Middelkoop, 1997). An additional effect of the embankment 


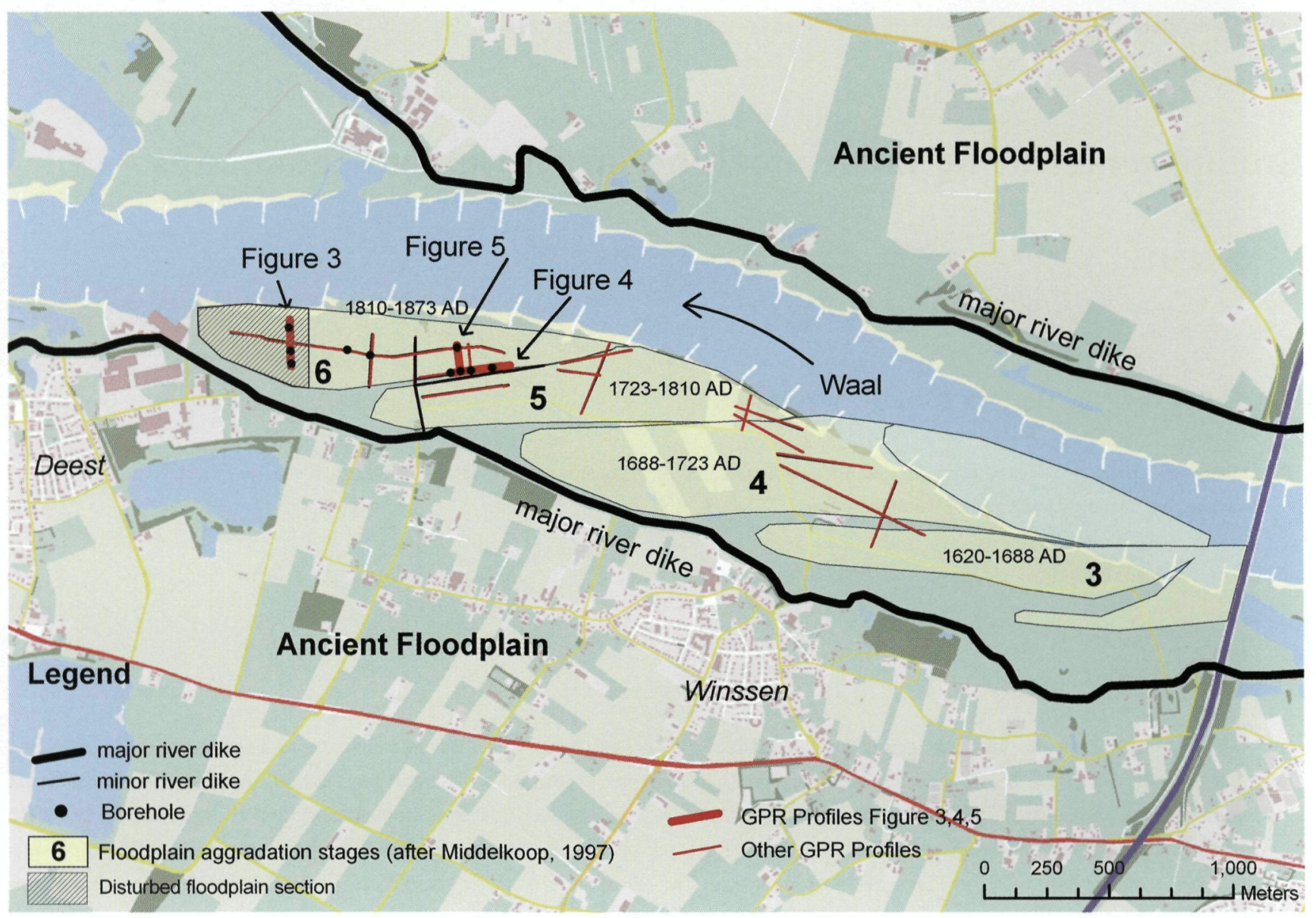

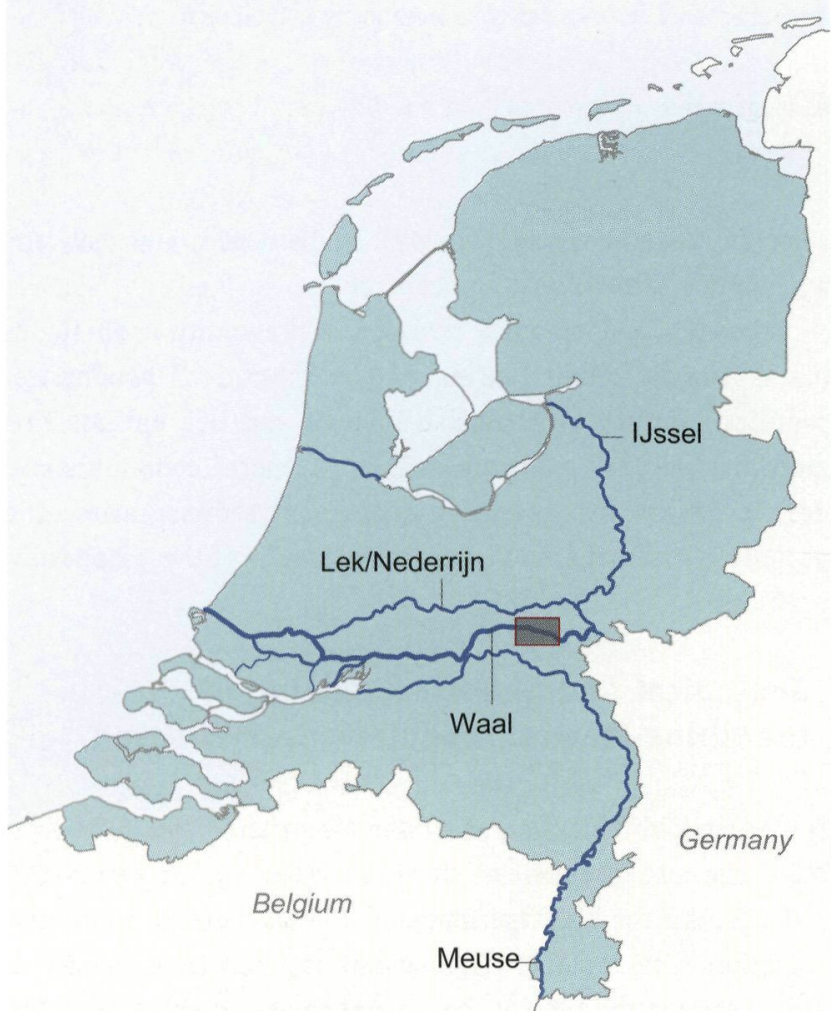

Fig. 1. Location of the study area with age indications of individual floodplain sections (after Middelkoop, 1997) and locations of the presented GPR profiles. was an increase in sedimentation rates within the restricted floodplain areas and a resulting decrease in water storage capacity. It is known from historical records (Middelkoop, 1997; Hesselink et al., 2003) that the first stages of embanked floodplain aggradation near Winssen took place around $1600 \mathrm{AD}$. The floodplain sections developed in a sequence of steps, which started with within-channel formation of islands and lateral accretion of bars, followed by vertical accretion due to overbank deposition and silting-up of swales and closed-off secondary channels (Hesselink et al., 2003). To assist land reclamation, groyne construction was initiated in the 17th century and continued subsequently during later stages. Around $1850 \mathrm{AD}$, the active river channel was straightened and a regular groyne array was constructed, resulting in a narrow and deep river channel (Hesselink et al., 2003).

During high discharges the embanked floodplains are still subject to flooding and vertical aggradation. The average flood frequency is about 40 to 45 times in $100 \mathrm{yr}$ for the Winssen floodplains (Middelkoop, 1997). The average accumulation rate is about $0.6-0.8 \mathrm{~cm} / \mathrm{yr}$ over the last $100 \mathrm{yr}$ (data based on Middelkoop, 1997). The overbank clays have relatively high concentrations of heavy metals, the result of high discharges of municipal and industrial waste water in the river from the end of the 19th century until the 1970's. 
Borehole data (Middelkoop, 1997; Berendsen et al., 2001; Hesselink et al., 2003) have shown that the sedimentary record of the embanked floodplains can be grouped into channel deposits consisting of coarse sand, abandoned residual channel deposits consisting of fine sand and clay locally with intercalated peat, and overbank deposits consisting of sandy clay and very fine to medium coarse sands. The study presented here involved GPR surveying of these deposits on three embanked floodplain segments (Fig. 1), which are largely undisturbed. These floodplain segments were formed from 1688 - $1723 \mathrm{AD}$ (referred to as floodplain section 4 in Middelkoop, 1997), 1723 - $1810 \mathrm{AD}$ (section 5) and 1810-1873 AD (section 6) respectively. Land-use in the floodplain is mainly pasture; some arable land and areas of nature rehabilitation are also present. In the very western part, sand has been excavated (Fig. 1).

\section{Ground-penetrating radar (GPR)}

Ground-penetrating radar (GPR) is a non-destructive profiling technique based on the propagation and reflection of electromagnetic waves. Reflections are generated at interfaces in the subsurface between materials with distinct dielectric properties. Changes in dielectric properties are mainly the result of differences in moisture content related to differences in lithology and mineralogy (e.g. Van Dam \& Schlager, 2000; Van Dam et al., 2002). GPR has been used successfully in sedimentological studies over recent years by providing insight in two and three dimensions, also in studies of fluvial deposits (e.g. Bridge et al., 1995; Vandenberghe and Van Overmeeren, 1999). See Neal (2004) for a review of the application of GPR in sedimentology.

$100 \mathrm{MHz}$ GPR antennas (PulseEKKO PRO) were used throughout the survey presented here as they seemed to provide the optimum between resolution and depth penetration at this site. The GPR had to penetrate through the overbank top clay drape (1 - $3 \mathrm{~m}$ thick). The data were collected in common-offset mode with an antenna separation of $1.0 \mathrm{~m}$ and a step size of $0.25 \mathrm{~m}$.

Processing of the raw GPR data included the application of an AGC gain (Automatic Gain Control) to enhance deeper reflectors, trace-to-trace filtering, down-the-trace filtering and topographic correction (see Neal (2004) for these processing applications). The concept of radar facies identification is applied (Jol, 1993; Vandenberghe and Van Overmeeren, 1999). Radar facies are defined as 'mapable three dimensional units composed of reflections whose parameters (e.g. magnitude, continuity, inclination) differ from adjacent units' (definition modified from Mitchum (1977) by Jol (1993)).

After processing of the GPR profiles and the discrimination of radar facies, sedimentary data from hand augering and a vibracoring campaign were compared with the radar facies. A total of 36 boreholes was made with an Edelman hand auger to determine the thickness of the topmost clay layer, to verify radar facies units and the depths of reflectors. Five vibracores were carried out for the same purpose (Fig. 6). Additionally, samples were taken from the cores for geochemical analysis and OSL dating.

The GPR surveys on floodplain section 6 were carried out in October 2004 and the surveys on section 4 and 5 were completed in July 2005. No flooding of the embanked floodplains had occurred during the previous months and river level was low. Amounts of rainfall had been somewhat less than normal in the previous months. At the time of surveys the groundwater table was at $\sim 3 \mathrm{~m}$ depth. All the GPR transects were recorded on pasture.

\section{On velocity analysis and groundwave characteristics}

Common mid point (CMP) analyses are used to calculate the radar velocity in the sediment from the direct groundwave (compare Jol and Smith, 1991; Jol and Bristow, 2003) in areas with undisturbed top clays. At station $60.0 \mathrm{~m}$ in Fig. 4 the velocity is established at $0.06 \mathrm{~cm} / \mathrm{ns}$ and at station $150.0 \mathrm{~m}$ at $0.09 \mathrm{~m} / \mathrm{ns}$. At the latter location somewhat dryer conditions occur (reflected in the development of the grass), resulting in higher signal velocities. When an overall velocity of $0.07 \mathrm{~m} / \mathrm{ns}$ is applied on the entire profile, the positions of most reflections match with layer interfaces as observed in the cores and boreholes. This is also the velocity that is established by CMP at other locations in floodplain section 6 and 4.

GPR reflection profiles are characterized by the presence of an airwave and the direct groundwave (Fig. 2). On this data set, some comments have to be addressed to the nature of the groundwave. The sequence of top overbank clay, often overlying sand, is a reason to consider a possible signal interference of the groundwave with the first true reflection from this clay-sand interface. The overbank clay influences the appearance of the groundwave in a way demonstrated in Fig. 3, which shows a $100 \mathrm{MHz}$ transect recorded in the most western part of the study area. This area, see Fig. 1, has a lowered topography as a result of sand and gravel extraction. For this extraction the top overbank clay layer was temporarily removed. In this area the reflector at $\sim 35$ ns has a particular wavy character. Additionally, signals occur between the airwave and this reflector at a depth of $20-22 \mathrm{~ns}$. If this is the ground wave, a velocity of $0.05 \mathrm{~m} / \mathrm{ns}$ is calculated given an antenna separation of $1.00 \mathrm{~m}$. If the reflector at $\sim 35 \mathrm{~ns}$ is the ground wave, a velocity of only $0.03 \mathrm{~m} / \mathrm{ns}$ would be calculated. Considering the depth of specific targets as verified by boreholes, this seems be too low.

It is known from the cores and the hand augering that the lithology of in situ overbank clay is laterally and vertically homogenous. It varies, however, in thickness and moisture content due to slight differences in elevation, reflected in vegetation development. In contrast, the disturbed overbank clays show increased heterogeneity as a result of admixed sands and a variable amount of voids. The result is that the arrival time of the groundwave has slight changes in arrival time in this area. 
GPR configuration

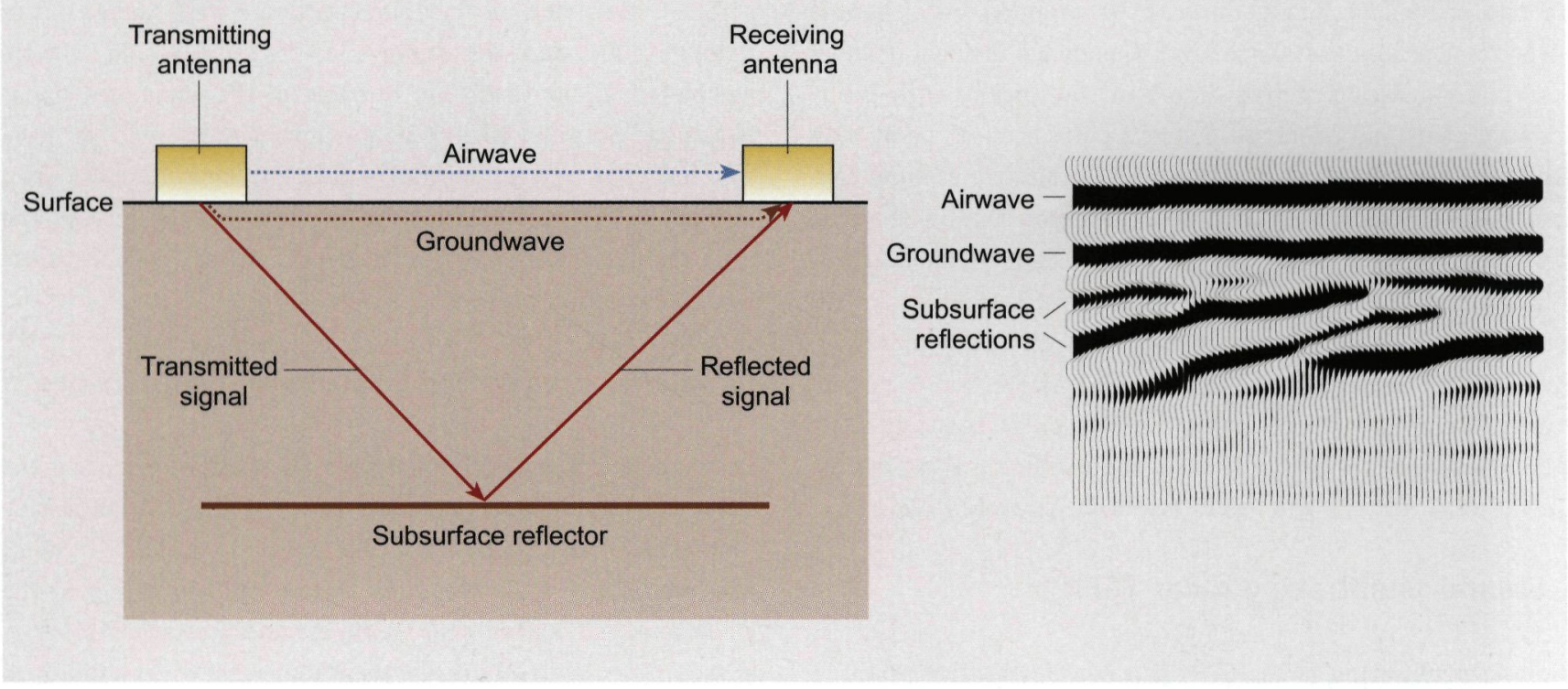

Fig. 2. Ray paths for the airwave, groundwave and reflected wave and example of resultant GPR profile (after Neal, 2004).

The reflection at $\sim 35$ ns in Fig. 3 is governed at the interface between the base of the clay refill and the underlying sediments. At positions were this interface is shallower (e.g. between 113 and $127 \mathrm{~m}$ along the profile), the reflection interferes with the ground wave and the latter is suppressed. So, in the area of the clay refill this GPR configuration (100 $\mathrm{MHz}$ antennae and $1.00 \mathrm{~m}$ separation) is suitable for establishment of clay thickness variability.

In the undisturbed area, signal velocity relies mostly on (very) slight differences in moisture content. Fig. 4 for example shows that the ground wave arrives slightly earlier above the sand bar unit (facies I) and somewhat later otherwise. Although this coincides with a thinner overbank layer (as shown by the cores) above the sand bar and thicker overbank clays on the sides, this is explained by differences in moisture content (i.e. dryer above the sandbar). The second reflector is thus interpreted as the groundwave with slightly variable arrival time over the reflected wave from the clay-sand interface.

When considering the nature of all the GPR profiles in the undisturbed area, it is most likely that the reflection from the bottom of the top clay is superimposed or interfering with the groundwave, hampering proper differentiation of the two in most cases. Considering this possible superposition additional measurements with $200 \mathrm{MHz}$ antenna and variation in antenna spacing would be worthwhile.

\section{Results}

All GPR profiles recorded on the floodplain sections 4, 5 and 6 have been studied in terms of radar facies units. Three distinct radar facies can be discriminated on the profiles (Figs $3-5$ ):
I. Westward (down-stream) dipping reflection sets, with well defined three dimensional geometry. These are interpreted as sand bars deposits.

II. Semi-transparent reflection sets, (sub-)horizontal to troughforms, locally concave reflection sets. The reflections are caused by fine sandy to clayey, laminated residual channel fill deposits, locally fining-upward.

III. Indistinct, irregular, subhorizontal reflection configurations, with limited three dimensional extent. Interpreted as sand dominated channel deposits, often gravelly.

GPR surveying and hand augering on the embanked floodplain section 5 (dated 1723 - $1810 \mathrm{AD}$, Fig. 1) shows that this section is covered by thick overbank top clay preventing sufficient GPR penetration. GPR imaging on the floodplain section 4a (dated 1688 - $1723 \mathrm{AD}$ ) however has revealed subsurface structures similar to the data presented in Figs 4 and 5.

\section{Interpretation}

As mentioned, overbank mud drapes and sand deposition has occurred along the Waal river channel (Ten Brinke et al., 1998) during (extreme) flood events. Away from the river channel the overbank sands occur in the form of sand bars. A clear example of such a sand bar (facies I) is imaged in Fig. 4. The lateral accretion surfaces of the lateral bar are distinct reflectors. At station $150.0 \mathrm{~m}$ a core was retrieved, presented in Fig. 6. A silt layer at $2.70 \mathrm{~m}$ depth reflects temporary slack water conditions.

On some GPR transects residual channels are recognized (Fig. 5), some with and some without morphological expression. According to Hesselink et al. (2003) their formation was the 

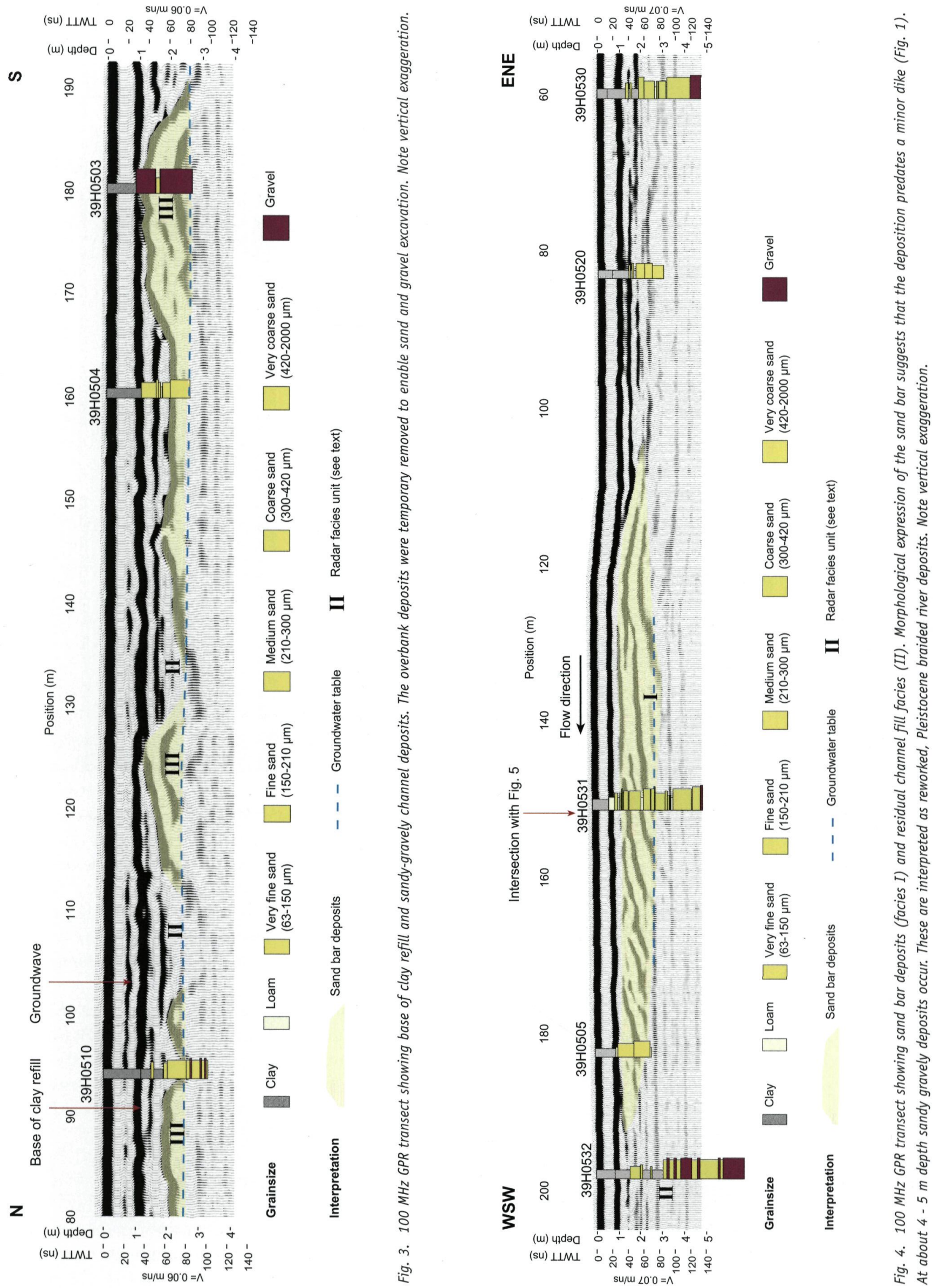
$\mathrm{su} / \mathrm{W} \angle 0^{\circ} 0=\wedge$

(su) $\perp M \perp \circ$ ㅇำ

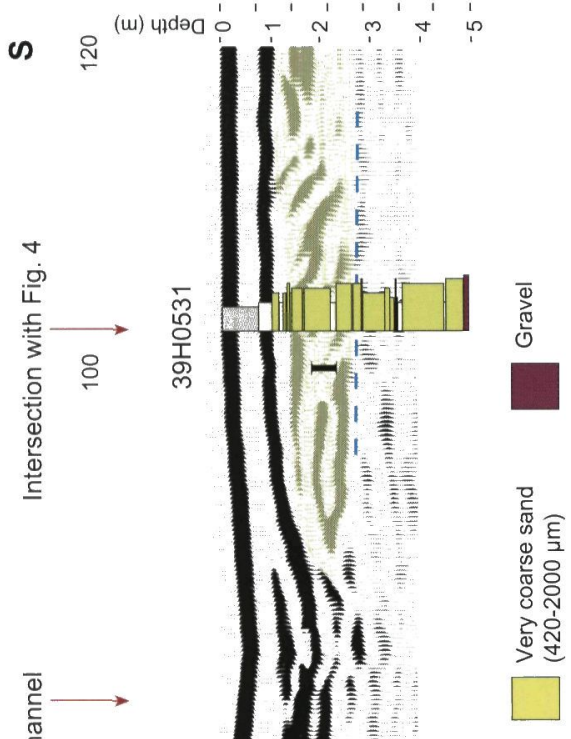

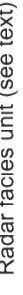

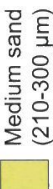

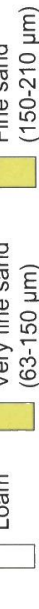

워

ำ

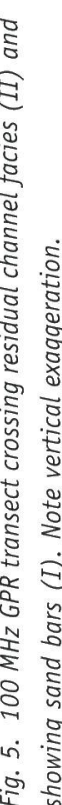

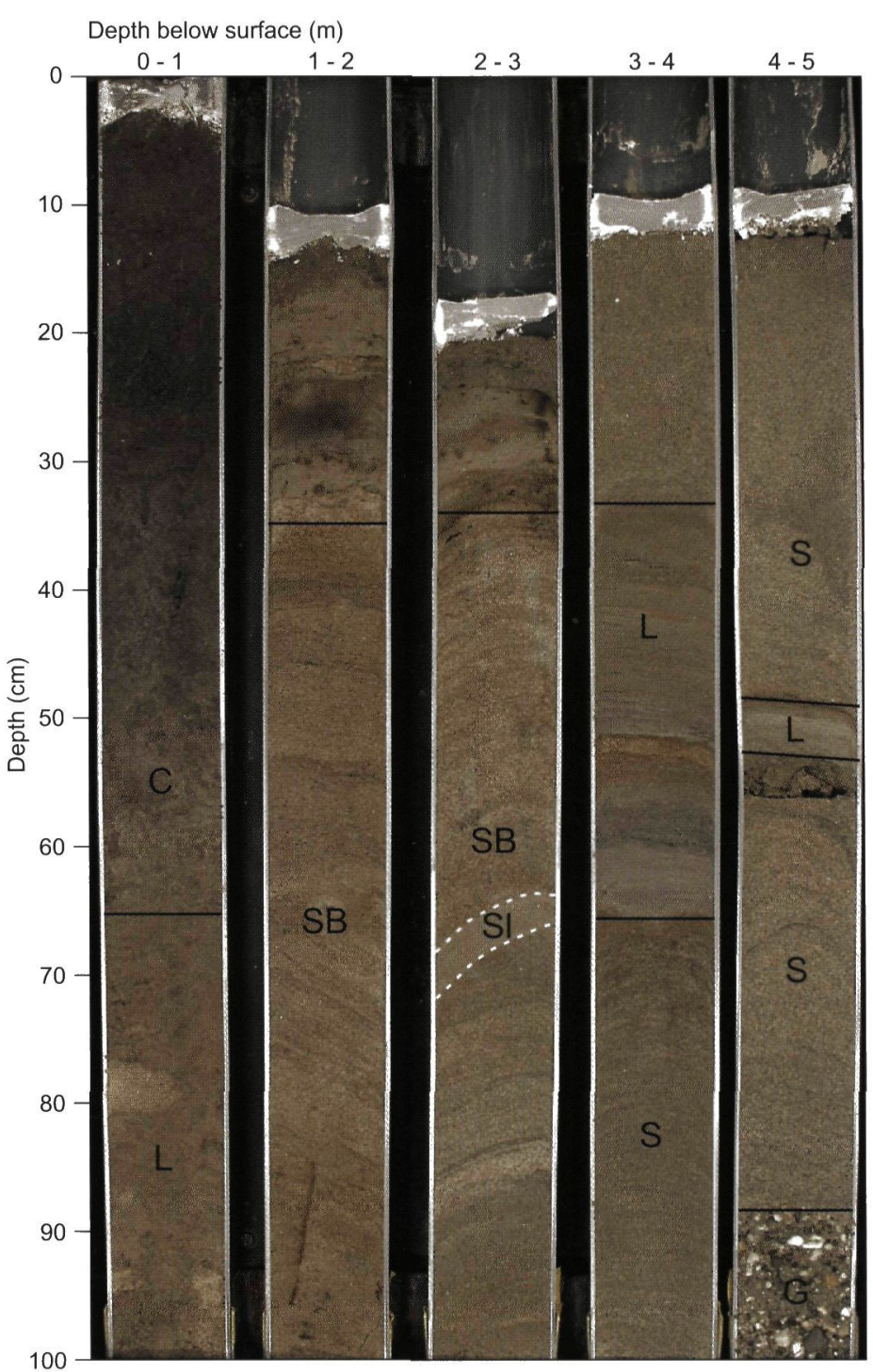

Fig. 6. Sediment core $39 H 0531$ showing clay drape (C), loams (L), silt layer $(S()$, sand bar deposits $(S B)$, undifferentiated sand deposits (S) and reworked Pleistocene gravels $(G)$. The structures in the upper part of the cores are unreliable due to disturbance by the coring process.

result of progressive land reclamation and acted as sediment traps for clay, silty clay and fine sand. The residual channels with morphological expression are still active during flood conditions.

Deeper coarse-grained channel deposits could not be imaged by GPR but are retrieved by a number of cores (see Figs 4, 5 and 6). Considering their elevated position relative to the undisturbed Pleistocene deposits outside the floodplain area, they are tentatively interpreted as reworked Pleistocene braided river deposits.

\section{Conclusions and forthcoming work}

GPR works well under given circumstances (relatively low groundwater table, after a period of low river discharge and an overbank top clay of less than $2 \mathrm{~m}$ thickness). GPR yields a 
very detailed 2.5-D picture of the facies assemblage including position and geometry of sedimentary units within embanked floodplain units. The method enables geometry establishment of sedimentary units without the need for dense drilling or cone-penetration test campaigns. This makes mineral exploration more economic.

Based on their appearance on the GPR transects, the development of sand bars seems more widespread in embanked floodplains than previously established. Sand bars deposited during recent floods are not preserved but commonly removed by land owners. The sand bars are the fingerprints of the high flow velocities induced by the embankments and the groynes. Their presence is therefore a reflection of the unnatural floodplain environment.

Ongoing geochemical analysis of all fine-grained beds will yield indirect information of sedimentation rates and will be combined with OSL dating of most coarse-grained architectural elements. All forthcoming results will be embedded in the geophysical framework presented in this paper. This has the major advantage that information from boreholes and such (i.e. point data) are fitted in sedimentary units of known geometrical extent.

\section{Acknowledgements}

Nederzand BV granted permission for the GPR profiling and coring on the Winssensche Waarden (Geertjesgolf). Gerard van Mameren, Hennie van de Putten and Wim Booltink are thanked for their efforts in the field. Harry Jol and Jan Brouwer are thanked for the discussions on the GPR interpretation.

J.S. Bridge and J. Vandenberghe are thanked for the critical assessment of the manuscript.

\section{References}

Berendsen, H.J.A., Faessen, E.L.J.H., Hesselink, A.W. \& Kempen, H., 2001. Zand in Banen, Zanddieptekaarten van het Gelders Rivierengebied met inbegrip van de uiterwaarden. Tweede herziene druk. Provincie Gelderland (in Dutch).

Bridge, J.S., Alexander, J., Collier, R.E.L.L., Gawthorpe, R.L. \& Jarvis, J., 1995. Ground-penetrating radar and coring used to study the large-scale structure of point-bar deposits in three dimensions. Sedimentology 42: 839-852.

Hesselink, A.W., Weerts, H.J.T. \& Berendsen, H.J.A., 2003. Alluvial architecture of the human-influenced river Rhine, the Netherlands. Sedimentary Geology 161: 229-248.

Jol, H.M., 1993. Ground Penetrating Radar (GPR): A New Geophysical Methodology used to Investigate the Internal Structure of Sedimentary Deposits. PhD thesis University of Calgary: $135 \mathrm{pp}$.

Jol, H.M. \& Smith, D.G., 1991. Ground penetrating radar of northern lacustrine deltas. Canadian Journal of Earth Sciences 28: 1939-1947.
Jol, H.M. \& Bristow, C.S., 2003. GPR in sediments: advice on data collection, basic processing and interpretation, a good practice guide. In: Bristow, C.S. \& Jol, H.M. (eds): Ground Penetrating Radar in Sediments. Geological Society (London), Special Publications 211: 9-27.

Middelkoop, H., 1997. Embanked floodplains in the Netherlands. Geomorphological evolution over various time scales. PhD-thesis Utrecht University, the Netherlands, Netherlands Geographical Studies 224: 341 pp.

Mitchum, R.M., Jr., 1977. Glossary of terms used in seismic stratigraphy. In: Payton, C.E. (ed.): Seismic stratigraphy - Applications to Hydrocarbon Exploration. American Association of Petroleum Geologists, Tulsa, 0klahoma, Memoirs 26: 135-143.

Neal, A., 2004. Ground-penetrating radar and its use in sedimentology: principles, problems and progress. Earth Science Reviews 66: 261-330.

Pons, L.J., 1957. De geologie, de bodemvorming en de waterstaatkundige ontwikkeling van het Land van Maas en Waal en een gedeelte van het Rijk van Nijmegen. PhD-thesis Wageningen University, the Netherlands. Verslagen van Landbouwkundige 0nderzoekingen: 63.11, $156 \mathrm{pp}$ (in Dutch).

Ten Brinke, W.B.M, Schoor, M.M., Sorber, A.M. \& Berendsen, H.J.A., 1998. Overbank sand deposition in relation to transport volumes during largemagnitude floods in the Dutch sand-bed Rhine river system. Earth Surface Processes and Landforms 23: 809-824.

Van Dam, R.L. \& Schlager, W., 2000. Identifying causes of ground-penetrating radar reflections using time-domain reflectometry and sedimentological analysis. Sedimentology 47: 435-449.

Van Dam, R.L., Schlager, W., Dekkers, M.J. \& Huisman, J.A., 2002. Iron oxides as a cause of GPR reflections. Geophysics 67: 536-545.

Vandenberghe J. \& Van Overmeeren, R.A., 1999. Ground-penetrating radar images of selected fluvial deposits in the Netherlands. Sedimentary Geology 128: $245-270$. 